\title{
RAPID METHODS TO SELECT FACULTATIVE PATHOGENS ON INVADER Cenchrus setaceus
}

\author{
Jorge SOPENA ${ }^{1}$, Natalia SIERRA CORNEJO ${ }^{1}$, Andreea COSOVEANU ${ }^{1}$, Carmen G. \\ RODRÍGUEZ ${ }^{2}$, Raimundo CABRERA ${ }^{1}$
}

${ }^{1}$ CIPEV Group, Department of Botany, Ecology and Plant Physiology, Biology Section, Faculty of Science, Universidad de La Laguna, Tenerife, Spain

${ }^{2}$ Gabinete de Estudios Ambientales (GEA), S.L.U., Tenerife, Spain

*Correspondence address:

Unit of Phytopathology, Grupo CIPEV, Dpt. Botany, Ecology and Plant Physiology,

Faculty of Sciences - Section Biology, Universidad de La Laguna, Bd. Astrofísico Francisco Sánchez.

Campus de Anchieta. P.O. Box 456, 38200, La Laguna, Tenerife, Canary Islands, Spain

Tel. 0034922318454,

Fax 0034922318447 ,

acosovea@ull.edu.es

http://www.doi.org/10.54574/RJPP.14.16

\begin{abstract}
Fountain grass, Cenchrus setaceus (Forssk.) Chiov. (syn. Pennisetum setaceum) is an invasive plant with high impact on insular environments such as the Canary Islands. Although there are no mentions on $C$. setaceus phytopathogens, plant communities with symptoms of withering, yellowing and decay have been found in Canary Islands. Our project aims to find autochthonous potential biological control agents for C. setaceus. Herein, we present a workflow in which we tested fast and cost-effective methods to screen a high number of fungal strains, aiming features like fast colonizers as well as competitive saprophytes and facultative pathogens with ability to cause infection. Affected plants were collected from the islands of Gran Canaria, Tenerife, La Gomera, La Palma and Lanzarote and 243 fungal strains belonging to 38 genera were isolated. First screening was performed on adult plants with pooled multiple species strains - spores suspensions of 10 random strains per pool, each strain representing a genus or a morphotype $(n=83)$. No symptoms of disease were observed. Most isolated genera in this study were Alternaria and Fusarium, known as cosmopolite phytopathogens. Next screening methods were focused accordingly. Two in vitro single-strain screening methods were employed by using mycelium-inoculated sectioned and entire leaves, to observe the ability of tissue colonization. First screening on sectioned leaves was performed with high amount of inoculum, to increase the chances of colonization and to determine the ability of fungi to use the plant material as substrate. The method was not effective in significantly reducing the number of candidates as most strains had abundant growth. To detect differences in fungal strains acting as facultative pathogens or phytopathogens, the $2^{\text {nd }}$ single-strain screening was performed on physiologically-stressed (pelargonic acid, a desiccant molecule to induce turgor loss) and not pre-treated leaves using less inoculum. Six strains were selected and subsequently evaluated in the last in vivo screening in the presence and absence of the desiccant. Finally, we detected strain 967 Fusarium clavum as able to colonize and reproduce at the crown of the young plants. In view of our experimental process, we propose a workflow for the cost-effective search for potential BCAs in similar situations.
\end{abstract}

Key words: IAP, phytopathogenic fungi, biological control, BCA

\section{INTRODUCTION}

Fountain grass, Cenchrus setaceus (Forssk.) Chiov. (syn. Pennisetum setaceum) is a C4 perennial wind-dispersed grass native to northeastern Africa widely used in horticulture as ornamental plant (Pablo Ferrer-Gallego Boiset, 2015). It is a strong fire-promoting invader of arid and semi-arid areas, and it has been introduced into South Africa, Australia, South Europe, USA, Hawaii, and Canary Islands (Adkins et al., 2011; González-Rodríguez et al., 2010; Poulin et al., 2005; Rahlao et al., 2014; Rodríguez-Caballero et al., 2017; Sinden et al., 2004). Alien invasive plants represent one of the major threats to native biodiversity especially on islands 
ecosystems due to their remoteness, small populations and high extinction rates (Walentowitz et al., 2019). In these environments, the influx of these species combined with other factors such as anthropogenic pressure and climate change lead to "the perfect storm", invasive species being the main driver of biodiversity loss (Caujapé-Castells et al., 2010). In Canary Islands $C$. setaceus was probably introduced in the $20^{\text {th }}$ century as ornamental plant and was early identified as potential invader displacing endemic species such as Hyparrenietalia hirtae and Oryzopsion miliacea (Betancort et al., 1999). C. setaceus is heterogeneously distributed in the Canary Islands. In La Palma, Tenerife and Gran Canaria colonizes large areas of land, while in the rest of the islands is spaced out in patches of smaller populations (see section Material and Methods - Figure 1).

C. setaceus is managed by multiple environmental management agencies and its control is of high priority enabling various searching tools and strategies to eradicate or diminish its spread. The strategies used to manage plant invaders are prevention, eradication, and control. Prevention policies are based on i) prohibiting imports of targeted species, ii) control of the main entry vehicles such as horticulture and iii) the development of predictive models (Reichard, 1997). When a species is in the early stages of the invasion, eradication should be a priority as it is only feasible according to the species-characteristics and generally within a low number of individuals, like so reducing costs and efforts. Classical weed control aims to limit or reduce invasive populations which cannot be eradicated. However, the strategies are not exempt of troubleshooting. Both mechanical control and chemical control can be really expensive, with impacts on ecosystems, as soil erosion and resistance to the active molecules (Clewley et al., 2012; Culliney, 2005; van Wilgen et al., 2013). In the last five decades, weed and alien plant control has been focused on bacterial and fungal plant pathogens (Li et al., 2003). Strategies such as bioherbicides have been developed based on the application of propagation biomass (i.e. fungal spores or bacteria suspensions) in concentrations that would not normally occur in nature (i.e. inundative biological control) (Johnson et al., 1996; TeBeest, 1996). The main benefit of bioherbicides is the reduction of environmental impacts associated to classical chemical management techniques, besides their lower cost, their high specificity and their ability to spread without human help (Auld Morin, 1995; Ghosheh, 2005; Hoagland et al., 2007; Johnson et al., 1996; Li et al., 2003). While in the earlier studies of biological control of weeds the use of imported insects and pathogens was considered safe, environmentally sound, and cost effective with savings up to millions of dollars (McFadyen, 1998), nowadays strategies are based on autochthonous organisms due to negative effects of allochthonous ones on ecosystems (Khan et al., 2008; Messing Wright, 2006). Conservation biological control (CBC) is a sustainable approach which relies on modification of the environment to protect and enhance natural enemies that are already present within the system (Peshin Zhang, 2014). This concept can be partially applied to our case study. Our project aims to find facultative pathogenic fungi associated to affected $C$. setaceus plants and introduce them back in the same site. The difference between insect pest control using natural enemies and invasive plants like $C$. setaceus using facultative pathogens is that these fungi present in the field need a weakened state of the host to act as potential control agents. So that the strategy to be feasible, it is necessary to achieve plant weakness (conservation phase) followed by increasing the fungal propagation biomass (flooding phase). Our project aims to find autochthonous potential biological control agents against $C$. setaceus. Although there are no mentions on $C$. setaceus phytopathogens, plant communities with symptoms of withering, yellowing and decay have been found in Canary Islands, opening the door to search for facultative pathogenic fungi. Herein, we present a workflow in which we tested fast and costeffective methods to screen a high number of fungal strains, aiming features like fast colonizers as well as competitive saprophytes and facultative pathogens with ability to cause infection. 


\section{MATERIAL AND METHODS}

\section{Collection of Samples}

Plants of $C$. setaceus were collected from Canary Islands (Gran Canaria, Tenerife, La Gomera, La Palma and Lanzarote). Plant individuals were visually analyzed for symptoms of diseases (spots, chlorosis, necrosis, etc.) and decay and finally 80 plants were selected (13 - La Palma, 5 - La Gomera, 1 - El Hiero, 12 - Tenerife, 42 - Gran Canaria and 7 - Lanzarote) (Figure 1). Plant organs (i.e. inflorescences, stems, leaves and roots) were separated in the field, placed in zip-bags and subsequently sections were stored at $4-5{ }^{\circ} \mathrm{C}$ in sterile centrifuge tubes $(50 \mathrm{ml})$ until further use. Samples were processed within $48 \mathrm{hrs}$.

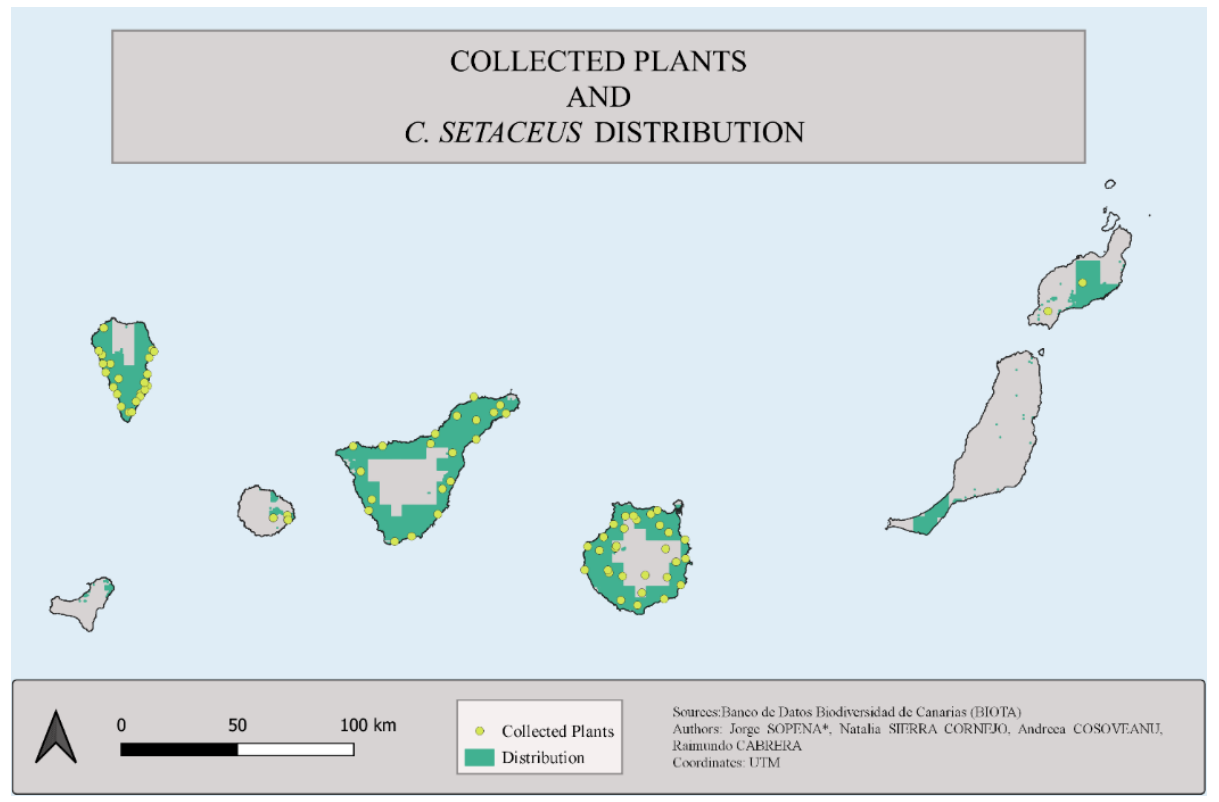

Figure 1. Map of C. setaceus distribution in Canary Islands and sites for collected plants

\section{Fungal Isolation and Conservation}

Plant fragments were only washed two times with sterile deionized water, for 1 minute each, under agitation. The plant material was dried on pieces of sterile filter paper under a laminar flow chamber and separated into fragments of approximately $2 \mathrm{~cm}$. The flowers were separated from the inflorescences before surface washing. Fragments were placed in potato glucose agar (PGA) plates with tetracycline $\left(10 \mathrm{mg} \mathrm{L}^{-1}\right)$ and incubated at $25^{\circ} \mathrm{C}$ in the darkness. Incubation time until purification of each strain was different according to strain velocity (2-5 days). Only strains with morphological differences were purified. Strains were maintained for short-and long-time conservation in mineral oil at $4-5{ }^{\circ} \mathrm{C}$ and $20 \%$ glycerol at $-22{ }^{\circ} \mathrm{C}$, respectively.

\section{Fungal Strains Identification}

Prior to taxonomic identification, a preliminary classification was made to avoid the selection of identical strains arising from the same plant individual, separating isolates into morphotypes according to (Cosoveanu et al., 2018). Briefly, we observed the shape and color of fungal colony and characteristics of reproductive organs under microscope. Selected strains were processed for DNA extraction, amplification, and sequencing by SEGAI (General Research Support Services of the University of La Laguna). Molecular identification of the 
fungal strains was performed using ITS1 (5'-TCCGTAGGTGAACCTGCGG-3') and ITS4 (5'TCCTCCGCTTATTGATATGC-3') primer pair to amplify the 5.8S rDNA and the two internal transcribed spacers ITS1 and ITS2 (White et al., 1990) The sequences were run through the BLASTN search page using Megablast program (National Center for Biotechnology Information; Bethesda MD, USA) where the most identical hits (> $98 \%$ for species and $>95 \%$ for genus) were obtained.

\section{In vivo Pools Screening}

To discard the possibility that fungal strains may act as potentially pathogens in the field, first screening was performed on adult plants of $C$. setaceus with multiple fungal species and strains per batch. Pooled spores suspensions of 10 random strains per batch with each strain representing a genus or a morphotype (except last three batches having 11 strains each) were used. In total 83 strains were evaluated. Spores suspensions were obtained by adding same amount of recovered mycelium from solid media per strain, in a sterile $50 \mathrm{ml}$ tube with sterile deionized $\mathrm{H}_{2} \mathrm{O}$, shaking with a vortex for 1 minute. Plants were inoculated with $10 \mathrm{ml}$ of solution using a glass laboratory sprayer coupled to multiple sheets of gauze to filter unbroken large size hyphae and allow the spores to pass through. Five plants per pool were inoculated and further watered normally and kept under observation for 45 days in greenhouse from October to December. In total, 45 plants were used (with five replicates as control). Daily evaluation was made to observe symptoms of disease. Treatments were completely randomized. To evaluate the pathogenic ability of the strains in Alternaria genus, similar pools were made with a collection of 30 strains. Spores suspensions of 10 random strains per pool were prepared as before explained. Three inoculation methods were preformed: i) foliar inoculation by adding a $10 \mu \mathrm{l}$ drop of spore suspensions on the leaf, ii) wounding the stem and injecting with a syringe $10 \mu 1$ spore suspensions and iii) wounding the leaf before inoculating with a pipette $10 \mu 1$ of spore suspensions. Six replicates (seedlings) were used per pool and inoculation method as well as control. Seedlings were maintained in greenhouse with regular watering and observations for disease symptoms were made once a week, during 45 days.

\section{In vitro Single Strain Screening}

Most isolated genera in this study were Alternaria and Fusarium, known as cosmopolite phytopathogens. Following screening methods targeted strains of these genera. Two screening methods were developed by using mycelium-inoculated leaf fragments and entire leaves, maintained in agarose, to observe the ability of tissue colonization. Healthy leaves were collected from plants maintained in greenhouses and sections of $7 \mathrm{~cm}$ were inoculated with high amount of mycelium. The fragments were handled with sterile forceps and rolled on actively growing mycelium of each strain. Three replicates (fragments) were used per strain. Fragments were introduced in 3\% agarose gel to maintain leaf moisture and force the strain to use as substrate the leaf. Fragments were maintained at $25^{\circ} \mathrm{C}$, in the dark, for 5 days. The evaluation was performed on the 2nd and 5th day after inoculation. Selection criteria for good colonizers was made with the following scale based on growth: $1=$ Low growth, $2=$ Mediumlow growth, 3 = Medium growth, $4=$ Medium-High growth, $5=$ High growth .

\section{In vitro Single Strain Screening +/- Stress Agent}

To detect differences in fungal strains acting as facultative pathogens or phytopathogens, a single-strain basic screening was performed on physiologically-stressed and normal leaves, using morphotypes strains of various species of Alternaria and Fusarium.

The method consists of leaves maintained hydrated in assay tubes with inoculation of a fungal strain. For this, $17 \mathrm{~cm}$ long healthy leaves were inserted in two $\mathrm{cm}$ of $3 \%$ agarose gel 
and tapped with moistened absorbent cotton and aluminum foil. This is a two-step method where in the first round healthy entire untreated leaves were inoculated and in the second round healthy pre-treated leaves with pelargonic acid were inoculated. Strains were inoculated by placing at the base of the leaf $0.5 \mathrm{~cm}$ mycelium disk collected from the actively growing hyphae in PDA. The leaves were treated with a desiccant molecule (i.e. pelargonic acid) in-house formulation modified after Fukuda et al. (2004) dispersion of pelargonic acid (PA) at 2,5\% with mineral oil and tween 20 in water (using a stock solution 3:1:1, PA:mineral oil:tween 20). Four different treatments were used: $\mathrm{T} 1=2.5 \%$ pelargonic acid, $\mathrm{T} 2=1.25 \%$ pelargonic acid, $\mathrm{T} 3=$ control with $\mathrm{H}_{2} \mathrm{O}$ and T4 = control with Tween 20 and mineral oil. Three leaves were used per strain and treatment. Only the strains which behaved as potential candidates as good colonizers in the first round (i.e. healthy leaves) were used in the second round (pre-treated leaves). For the evaluation of the strains, we proposed a series of selection criteria for good colonizers in both screenings: IG: Insignificant growth $<0.5 \mathrm{~cm}$, IMG: Growth inside agarose without necrosis, IMGN: Growth inside agarose with necrosis, OMGN: Growth on the leaf surface and symptoms of necrosis on the outside of the medium, NOS: No symptoms, AGM: Abundant mycelial growth $(<1 \mathrm{~cm})$ on the outside of the medium, colonizing the leaf $360^{\circ}$. To further discriminate between strains, we performed a scale based on the previously mentioned criteria. Selection of candidates was made according to the following groups of criteria: AGM, OMGN and IMGN = 3 points; AGM, OMGN or IMGN = 2 points; OMGN and/or IMGN = 1 point, IF there is NOS or IMG or IG $=0$.

\section{In vivo Single Strain Screening + Stress Agent}

The selected strains from the in vitro screenings were further assayed in vivo. Inoculations were performed using $2 \mathrm{ml}$ of spore suspensions $\left[1 \times 10^{6} \mathrm{ml}^{-1}\right]$ with $0.005 \%$ Tween 20 on pre-untreated seedlings and pretreated seedlings with $2 \mathrm{ml}$ of in-house formulation of PA at $2.5 \%$ (previously described). Spores suspensions and PA dispersion were applied with a glass laboratory sprayer. The treatments were as follows with 5 replicates (seedlings) per treatment: $\mathrm{T} 1=$ seedlings with spores suspensions, $\mathrm{T} 2=$ Seedlings with PA and spores solution, $\mathrm{T} 3=$ Seedlings with PA, T4 = Seedlings and dispersion of PA (mineral oil and tween 20, without active substance), T5 $=$ Not treated seedlings. Seedlings were maintained in the greenhouse for 5 weeks evaluating weekly the following parameters: the number of healthy leaves, the number of dry leaves and the number of leaves with spots.

\section{Statistical Analysis}

To determine the effect of fungal strains and pelargonic acid on seedlings, several linear mixed models were used. For each model we established the monitored variable as response variable, treatment and time as fixed factors (without interaction) and individual as random factor. Analyses were carried out with the 'Imer' function of the 'Ime4' package (Bates et al., 2015). Normality and homocedasticity of residuals was visually checked. Subsequently, to determine differences among groups, we carried out a Tukey's HSD post-hoc adjustment for multiple comparisons. All analyses were set to a significance level of $p<0.05$ and were performed using R software v.4.0.3 (R Core Team, 2020)

\section{RESULTS AND DISCUSSION}

Our fungal collection associated to affected plants of $C$. setaceus is represented by 243 strains with 38 genera and 83 morphotypes. Strains considered as morphotypes, representative for the species or species complexes were used for the present study. Among isolated genera, Fusarium and Alternaria stand out with 53 and 37 strains respectively. Both genera are widely 
known as serious plant pathogens of a variety plant species (Thrane et al., 1999; RojasHernandez et al., 2014; Thomma 2003; Iacomi-Vasilescu et al., 2004) with species already considered as potential mycoherbicides (Abdessemed et al., 2020; Barberi, 2019) and even used as such (Cook et al., 2009; Pacanoski, 2015). Thus, members of Fusarium and Alternaria were considered a priority in the search for candidates as further potential biological control agents (BCAs). However, the symptomatology detected in the field does not correspond to classical symptoms of these genera. During the initial field prospections four phases of evolution of decay of the $C$. setaceus affected plants in Tenerife were established - class I Healthy individuals (without apparent symptoms), class II Individuals with normal coloration (including yellowish) and small black spots on some parts of the plants, class III Individuals with a grey dark grey part of the plant that acquires a very brittle consistency and IV Individuals in which the dark grey-blackened part disappears (generally the central one), leaving only a few side shoots that mark the original perimeter of the plant (Rafael Paredes Gil, unpublished data). In addition, affected plant populations found in different islands showed similarities. Yet, the scarcity of physiological studies and the complete lack of previous mentions of any pathogens on this species makes difficult a targeted search. However, C. setaceus was reported to have a low $\mathrm{N}$ content in leaves, compared to native species in Tenerife (González-Rodríguez et al., 2010). Facultative pathogens are known to increase in severity with low N supply of plant tissue (Dordas, 2008). Therefore, we ventured confident in a search for a suitable method to detect fast colonizers of stressed plants (i.e. facultative pathogens). Pooled screenings in planta and in vitro were performed to survey the diversity of the fungal collection in a fast and inexpensive manner, using combinations of different fungal species as well as representatives of the same genus (i.e. Alternaria and Fusarium). Both pooled screenings in planta - i) 83 strains of different species and genera and ii) 30 strains of Alternaria resulted in no symptoms on plants. Pooled screenings on plants might have been ineffective for a series of reasons: i) randomly selected strains may compete, ii) by selecting morphotypes we might have missed pathogenic strains and iii) effects of treatments cannot be easily detected as the nature of plant interferes rapidly producing new leaves, with mature leaves turning yellow and curly. Although the screenings were unsuccessful for this plant model, we consider that the cost-benefit of performing similar assays to search for BCAs in other weeds is still useful. The closer to natural conditions an assay is, the easier the steps leading to a good BCA would be.

From species-diverse screenings we moved towards single-strain screening, focusing on Alternaria and Fusarium both because of their abundance in our collection and because of their known behavior as cosmopolite phytopathogens (Woudenberg et al., 2015). For this purpose, we performed in vitro screenings with sectioned leaves looking for strains capable of colonizing plant tissues. First screening on sectioned leaves was performed with high amount of inoculum, to increase the chances of colonization, since no colonization was actually observed in previous assays (i.e. pooled screenings). This assay aimed to determine the ability of fungi to use the plant material as substrate. The method was not effective in reducing the number of candidates as most strains had abundant growth, apparently being good colonizers of the plant substrate (Figure 2). Of 30 tested strains of Alternaria, 23 of them were able to colonize leaf tissues abundantly after 5 days. 

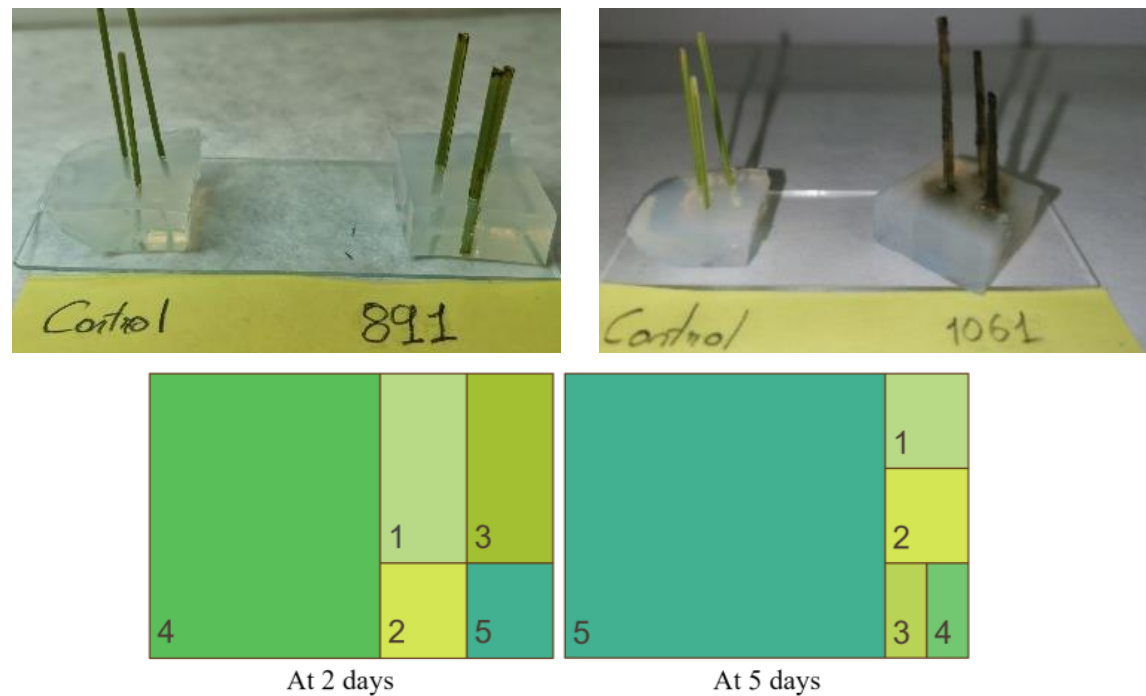

Figure 2. Pooled screening on leaves fragments with high inoculum. Images display two tested strains with different behaviour and controls. Treemap displaying hierarchical data of interpretation scale of strains. Scale interpretation of leveles of fungal growth: 1 - Low growth,

2 - Medium-low growth, 3 - Medium growth, 4 - Medium-High growth, 5 - High growth

Single-strain screening was further exploited using less inoculum $(5 \mathrm{~mm}$ diameter of fungal mycelium) with both healthy leaves and pre-treated leaves with a stress molecule pelargonic acid, a desiccant molecule to induce turgor loss (Ciriminna et al., 2019; Dayan et al., 2009) and allow facultative pathogens to install and colonize. The assay was performed in closed assay tubes to maintain high humidity and the agarose gel at $3 \%$ showed to be a good choice matrix to support hydration the leaf. The screening on healthy leaves showed three fungal strains with abundant growth and symptoms of necrosis (Figure 3 ).

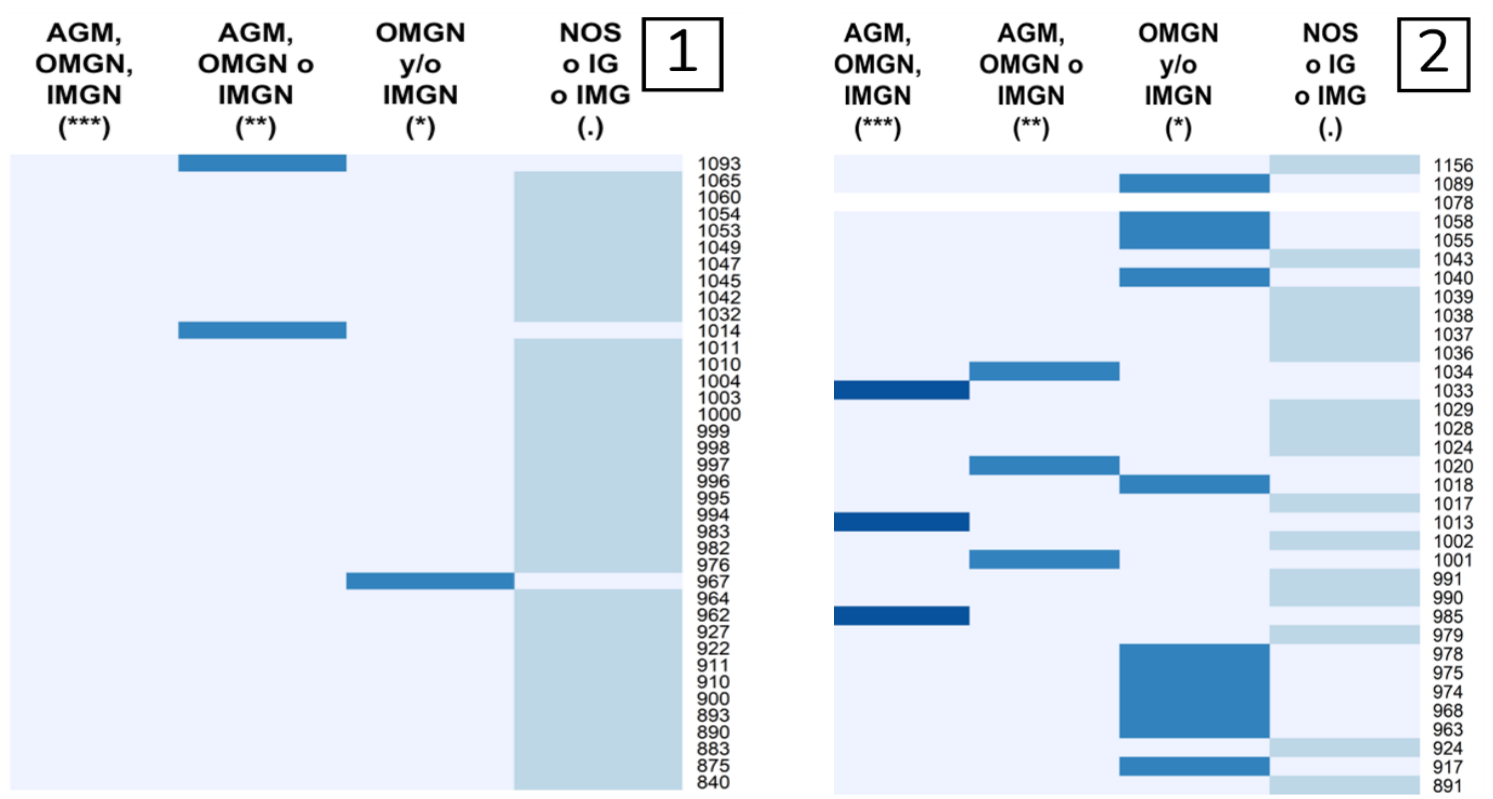

Figure 3. Heat maps with grouped symptoms detected in single-strain screening: 1 - Fusarium, 2 - Alternaria. IG Insignificant growth $<0.5 \mathrm{~cm}$, IMG - Growth inside agarose without necrosis, IMGN - Growth inside agarose with necrosis, OMGN - Growth on the leaf surface and symptoms of necrosis on the outside of the medium, NOS - No symptoms, AGM - Abundant mycelial growth $(<1 \mathrm{~cm})$ on the outside of the medium, colonizing the leaf $360^{\circ}$. Different shades of blue indicate further interest in fungal strains producing grouped symptoms 
Subsequently, 13 strains were selected for the assay on pre-treated leaves with pelargonic acid -1001 (A. arborescens), 1013, 1034, 1020, 1033 and 985 (Alternaria angustivoidea), 1156 (A. destruens), 1078 (Alternaria sp.), 1093 (Fusarium chlamydosporum) and 967 (F. clavum). Six strains (967, 1001, 1013, 1020, 1033 and 1034) showed good growth and necrosis symptoms (Table 1), therefore were considered as potential candidates for the in vivo assay.

Table 1. Single-strain screening evaluation on pre-treated leaves with pelargonic acid. Treatments: T1 - 2,5\%, $\mathrm{T} 2$ - 1,25\%, T3 - control with $\mathrm{H} 2 \mathrm{O}$ and T4 - control with Tween 20 y aceite mineral. IG - Insignificant growth $<0.5 \mathrm{~cm}$, IMG - Growth inside agarose without necrosis, IMGN - Growth inside agarose with necrosis, OMGN

- Growth on the leaf surface and symptoms of necrosis on the outside of the medium, NOS - No symptoms,

AGM - Abundant mycelial growth $(<1 \mathrm{~cm})$ on the outside of the medium, colonizing the leaf $360^{\circ}$.

\begin{tabular}{|c|c|c|c|c|c|c|c|}
\hline Strain & Treatment & IG & IMG & IMGN & NOS & OMGN & AGM \\
\hline 967 & T1 & & & & & $\mathrm{X}$ & $\mathrm{X}$ \\
\hline 967 & $\mathrm{~T} 2$ & & & & & $X$ & $\mathrm{X}$ \\
\hline 967 & T3, T4 & & & & $\mathrm{X}$ & & \\
\hline 985 & T1 & $\mathrm{X}$ & & & & & \\
\hline 985 & $\mathrm{~T} 2$ & $X$ & & & $\mathrm{X}$ & & \\
\hline 985 & T3,4 & $\mathrm{X}$ & & & $\mathrm{X}$ & & \\
\hline 1001 & T1 & & & & & $\mathrm{X}$ & $\mathrm{X}$ \\
\hline 1001 & $\mathrm{~T} 2$ & $X$ & & & $\mathrm{X}$ & & \\
\hline 1001 & $\mathrm{~T} 3,4$ & $\mathrm{X}$ & & & $\mathrm{X}$ & & \\
\hline 1013 & T1 & & & & & $\mathrm{X}$ & $\mathrm{X}$ \\
\hline 1013 & $\mathrm{~T} 2$ & $X$ & & & & & \\
\hline 1013 & T3, T4 & $\mathrm{X}$ & & & $\mathrm{X}$ & & \\
\hline 1020 & T1 & & & & & $X$ & $\mathrm{X}$ \\
\hline 1020 & $\mathrm{~T} 2$ & & & & & & \\
\hline 1020 & $\mathrm{~T} 3,4$ & & & & & & \\
\hline 1033 & T1 & & & & & $\mathrm{X}$ & $\mathrm{X}$ \\
\hline 1033 & $\mathrm{~T} 2$ & & & & & $X$ & $\mathrm{X}$ \\
\hline 1033 & $\mathrm{~T} 3,4$ & & & & & & \\
\hline 1034 & T1 & & & & & $\mathrm{X}$ & $\mathrm{X}$ \\
\hline 1034 & T2 & & & & & $\mathrm{X}$ & $\mathrm{X}$ \\
\hline 1034 & T3,4 & $\mathrm{X}$ & & & $\mathrm{X}$ & & \\
\hline 1093 & T1 & & & & & $\mathrm{X}$ & $\mathrm{X}$ \\
\hline 1093 & T2 & $\mathrm{X}$ & & & & & \\
\hline 1093 & T3,4 & $\mathrm{X}$ & & & & & \\
\hline
\end{tabular}

The in vivo single-strain assay with pelargonic acid (PA) was performed with the six candidate strains on young plants to i) observe the potential synergistic interaction between the dessicant and the fungal strains and ii) to determine both the effect and the duration of dessicant application. Pelargonic acid pre-treatment decreased healthy leaves/total leaves ratios significantly ( $\mathrm{p}<0.05$ ), compared to the total number of leaves (Figure 4). However, after 15 days, plants pre-treated with PA recovered and showed a higher proportion of healthy leaves compared to the previous week $(\mathrm{p}<0.05)$. Still, until the end of the follow-up, the plants pretreated with PA and inoculation of strains presented a lower ratio of healthy leaves/total number of leaves than their corresponding groups treated only with fungal strains, dispersion and water solutions. Hence, plants treated with PA remained weakened for at least a month and a half (total duration time of the assay) and slowly recovered. We appreciated that in the future assays, there would be a need for a second dose of PA, preventing the total recovery of plants. Symptoms of alternariosis were observed in plants treated with 1020 and 1033 of $A$. angustivoidea. Yet, ratios of leaves with spots/healthy leaves were only significantly different 
for the strain 1020 in plants pre-treated with PA, at the end of the first week, compared to the rest of the treatments and controls $(\mathrm{p}<0.05)$ (Figure 4). After 2 weeks-time, treatments were not different than controls, irrespective of type.
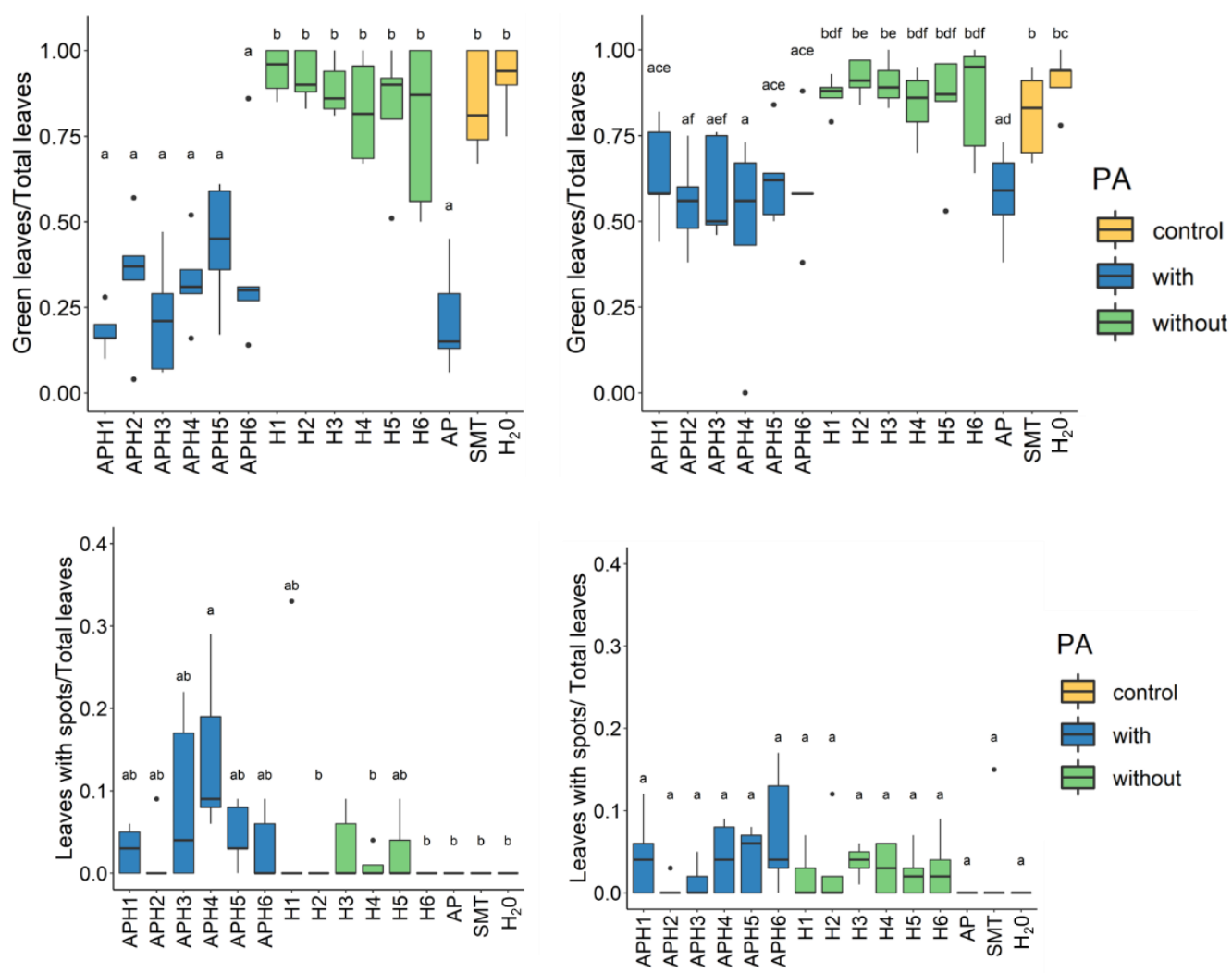

Figure 4. In vivo single-strain assay with pelargonic acid. Upper side - distribution of values for healthy leaves/total leaves of treatments with the six fungal strains (H1-H6), pre-treated leaves with pelargonic acid (APH1-APH6), and controls (PA - pelargonic acid, SMT - solution of mineral oil and tween 20, H2O). Bottom side - distribution of values for leaves with spots/total leaves in the same treatments as before. H1 967, H2 - 1001, H3 - 1013, H4 - 1020, H5 - 1033 and H6 - 1034. Evaluation was made after 1 week (first column) and 2 weeks (second column).

Meaningful to mention that although the assay was initially considered to have a duration of 4 weeks, we have maintained the plants in the same conditions for another month. During the second month, results with A. angustivoidea strain 1020, our best candidate at that time, were not favourable. The leaves damage caused by Alternaria strains was not significant, the candidate progressed extremely slow (i.e. small changes in number of leaves with spots no relevant dissemination was observed on the proximity leaves and spots did not increase rapidly in size). While these observations were leading us towards a next assay with improved conditions for strain 1020, we have observed that random plants with dehydration appearance, turned yellow and died. We were able to detect that plants were colonized by the strain $967 \mathrm{~F}$. clavum. The dissemination of the strain was among plants treated with $\mathrm{PA}, \mathrm{H}_{2} \mathrm{O}$ and dispersion solution controls, besides plants treated voluntarily. As the disease progressed, the fungus began to produce mycelia and sporodochia from white to light salmon colour, at the crown (Figure 5). The strain 967 was recovered from all the symptomatic plants confirmed by microscope observations to compare with the originally inoculated strain (i.e. macroconidia characteristics). 
Finally, its presence was confirmed by molecular identification using both ITS region and the translational elongation factor $1 \alpha(\operatorname{TEF} 1 \alpha)$.
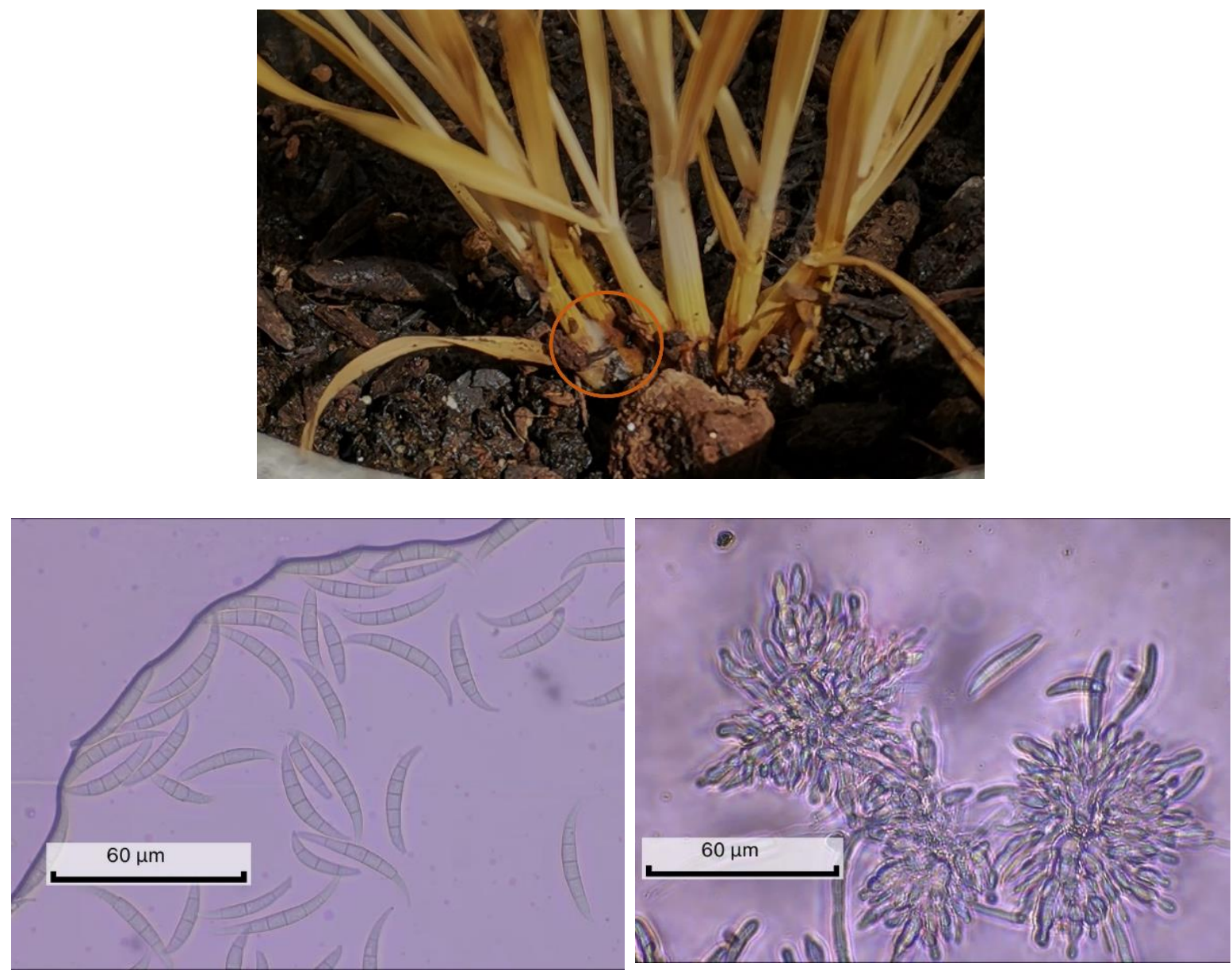

Figure 5. Up - C. setaceus young plant dried out plant with the left side of the crown covered partially by mycelium and sporodochia of strain 967 F. clavum. Bottom, left - macroconidia of strain 967 F. clavum and right - sporodochia of strain 967 F. clavum

In view of our experimental process, we propose the following workflow for the costeffective search for potential BCAs in similar situations (Figure 6). The diverse fungal collection is screened using pooled in vivo assays. If pathogenicity is observed, each strain should be evaluated separately for pathogen-like features. If pathogenicity has occurred in the pool assay but not in the single strain assay, it might be the case of a consortium causing pathogenesis. If there is no pathogenicity in the pooled screenings, in vitro assay with singlestrain would be the next road. If good colonisers are found in the in vitro single-strain assay and pathogenicity occurs thereafter in vivo assays, we have another potential pathogen. If a good colonising strain is found but no pathogenicity is observed, it is mandatory to change the inoculation methods. If no good colonisers are found in vitro assays, the search would focus on facultative pathogens. For this, a stress factor for the plant tissue is added to the assays. Optimisation of the parameters under which pathogenesis occurs can be critical. 


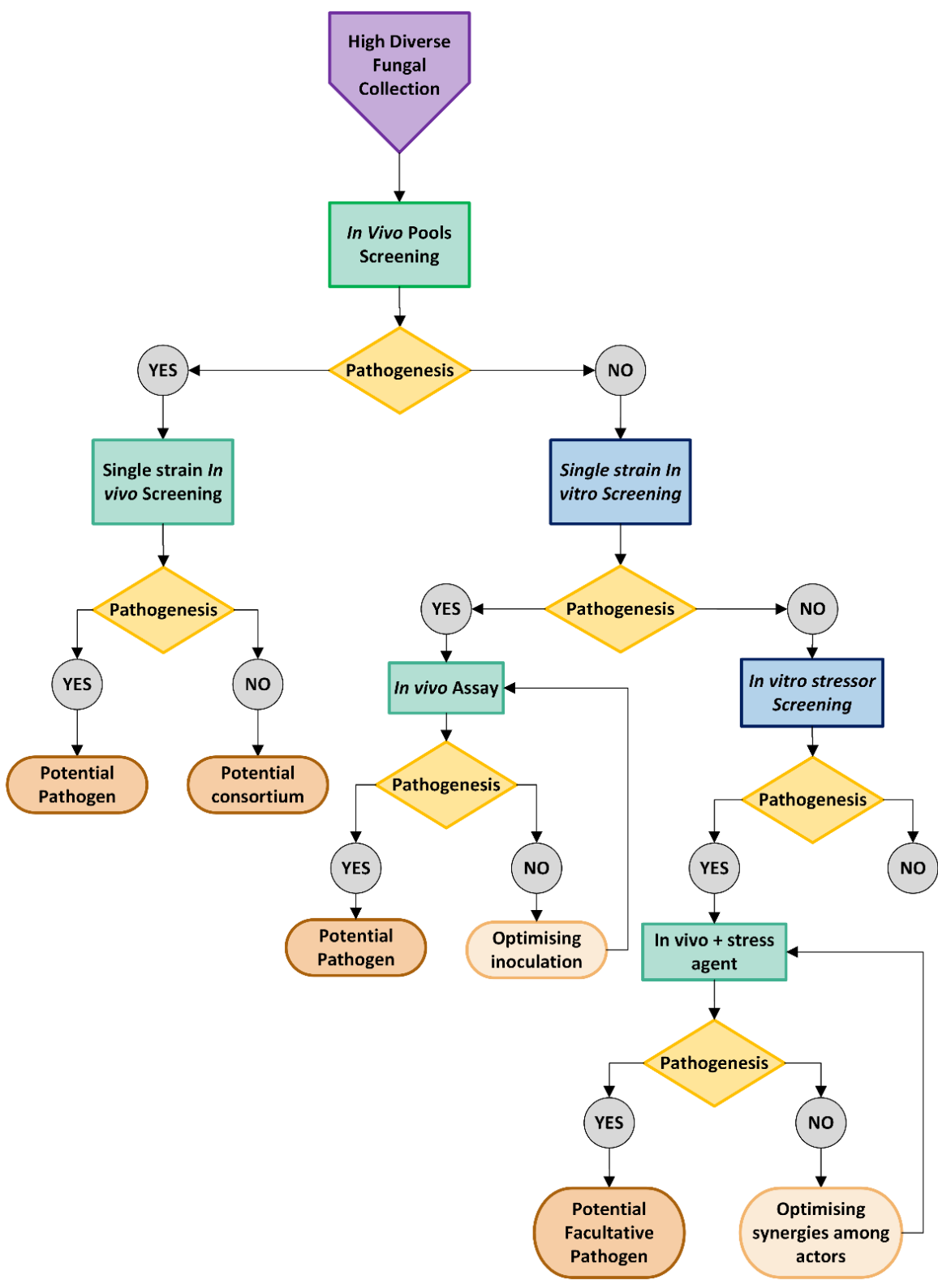

Figure 6. Proposed workflow for screening of a diverse fungal collection as potential fungal pathogens or facultative pathogens

\section{CONCLUSION}

When an invasive species is already established, the only way of management are longterm control programs. Although fungal pathogens have a great potential as biological control agents, search is time and cost consuming, especially when number of strains to test is high. The workflow of screening methods we propose, together with the selected combination of features to choose pathogenic strains, may help researchers in the hunt of fungal strains as potential biological control agents in a cost-effective manner. Screenings with sectioned leaves give information on the ability of the fungal strains to colonize plant tissue, results being biased when inoculum is used in large amount. In planta pooled screenings need multiple optimizations as various factors may influence the interaction: i) pre-existent microbiome, ii) artificially inoculated fungal complex interaction and iii) abiotic factors. By far, we consider 
that screening with detached leaves and moderate inoculum could pave the way for good fungal colonizers, followed by in vivo screening with "one strain-one plant" which could indicate good candidates for BCAs.

\section{ACKNOWLEDGEMENTS}

This work is part of the project "Nuevas técnicas de control del rabogato, Pennisetum setaceum", funded by Consejería de Transición Ecológica, Lucha contra el Cambio Climático y Planificación Territorial, Gobierno de Canarias. The work has been carried out with the authorization for access Spanish plant genetic resources (Ministerio para la Transición Ecológica y Reto Demográfico ref. ESNC54). The authors are grateful to private body Gabinete de Estudios Ambientales (GEA Tenerife) for the help with the field activities and first-hand knowledge.

\section{REFERENCES}

ABDESSEMED, N., BAHET, Y. A., ZERMANE, N. (2020). Mycoherbicide potential of Alternaria alternata (Fries.) Kiessler and its formulations on the host weed Xanthium strumarium L. Biocontrol Science and Technology, 1-16. Doi: 10.1080/09583157.2020.1814692

ADKINS, E., CORDELL, S., DRAKE, D. (2011). Role of Fire in the Germination Ecology of Fountain Grass (Pennisetum setaceum), an Invasive African Bunchgrass in Hawai'i. Pacific Science, 65, 17-25. Doi: $10.2984 / 65.1 .017$

AULD, B. A., MORIN, L. (1995). Constraints in the Development of Bioherbicides. Weed Technology, 9, 3, 638-652. Doi: 10.1017/S0890037X00023964

BARBERI, P. (2019). Ecological weed management in Sub-Saharan Africa: Prospects and implications on other agroecosystem services. In: Donald L. Sparks (Ed), Advances in Agronomy, 156, 219-264. Academic Press. Doi: 10.1016/bs.agron.2019.01.009

BATES, D., MÄCHLER, M., BOLKER, B., WALKER, S. (2015). Fitting Linear Mixed-Effects Models Using Lme4. Journal of Statistical Software, 67, 1-48. Doi: 10.18637/Jss.V067.I01

BETANCORT, J.A.R., ARENCIBIA, M., GALLO, A. (1999). Consideraciones acerca del género Pennisetum en Canarias (Magnoliophyta, Poaceae). Vieraea: Folia Scientarum Biologicarum Canariensium, 27, 205-216.

CAUJAPÉ-CASTELLS, J., TYE, A., CRAWFORD, D.J., SANTOS-GUERRA, A., SAKAI, A., BEAVER, K., LOBIN, W., VINCENT FLORENS, F. B., MOURA, M., JARDIM, R. (2010). Conservation of oceanic island floras: Present and future global challenges. Perspectives in Plant Ecology, Evolution and Systematics, 12, 2, 107-129. Doi: 10.1016/j.ppees.2009.10.001

CIRIMINNA, R., FIDALGO, A., ILHARCO, L.M., PAGLIARO, M. (2019). Herbicides based on pelargonic acid: Herbicides of the bioeconomy. Biofuels, Bioproducts and Biorefining, 13, 6, 14761482. Doi: 10.1002/bbb.2046

CLEWLEY, G.D., ESCHEN, R., SHAW, R.H., WRIGHT, D.J. (2012). The effectiveness of classical biological control of invasive plants. Journal of Applied Ecology, 49, 6, 1287-1295. Doi: 10.1111/j.1365-2664.2012.02209.x

COOK, J.C., CHARUDATTAN, R., ZIMMERMAN, T.W., ROSSKOPF, E.N., STALL, W.M., MACDONALD, G.E. (2009). Effects of Alternaria destruens, glyphosate, and ammonium sulfate individually and integrated for control of dodder (Cuscuta pentagona). Weed Technology, 23, 550-555. Doi: 10.1614/wt-08-019.1

COSOVEANU, A., RODRIGUEZ SABINA, S., CABRERA, R. (2018). Fungi as Endophytes in Artemisia thuscula: Juxtaposed Elements of Diversity and Phylogeny. Journal of Fungi, 4, 1, 17. Doi: $10.3390 /$ jof 4010017

CULLINEY, T.W. (2005). Benefits of Classical Biological Control for Managing Invasive Plants. Critical Reviews in Plant Sciences, 24, 2, 131-150. Doi: 10.1080/07352680590961649

DAYAN, F.E., CANTRELL, C.L., DUKE, S.O. (2009). Natural products in crop protection. Bioorganic Medicinal Chemistry, 17, 12, 4022-4034. Doi: 10.1016/j.bmc.2009.01.046 
DORDAS, C. (2008). Role of nutrients in controlling plant diseases in sustainable agriculture. A review. Agronomy for Sustainable Development, 28, 1, 33-46. Doi: 10.1051/agro:2007051

FUKUDA, M., TSUJINO, Y., FUJIMORI, T., WAKABAYASHI, K., BÖGER, P. (2004). Phytotoxic activity of middle-chain fatty acids I: Effects on cell constituents. Pesticide Biochemistry and Physiology, 80, 3, 143-150. Doi: 10.1016/j.pestbp.2004.06.011

GHOSHEH, H. Z. (2005). Constraints in implementing biological weed control: A review. Weed Biology and Management, 5, 3, 83-92. Doi: 10.1111/j.1445-6664.2005.00163.x

GONZÁLEZ-RODRÍGUEZ, A. M., BARUCH, Z., PALOMO, D., CRUZ-TRUJILLO, G., JIMÉNEZ, M. S., MORALES, D. (2010). Ecophysiology of the invader Pennisetum setaceum and three native grasses in the Canary Islands. Acta Oecologica, 36, 2, 248-254. Doi: 10.1016/j.actao.2010.01.004

HOAGLAND, R.E., BOYETTE, C.D., WEAVER, M.A., ABBAS, H.K. (2007). Bioherbicides: Research and Risks. Toxin Reviews, 26, 4, 313-342. Doi: 10.1080/15569540701603991

IACOMI-VASILESCU, B., AVENOT, H., BATAILLE-SIMONEAU, N., LAURENT, E., GUENARD, M., SIMONEAU, P. (2003). In vitro fungicide sensitivity of Alternaria species pathogenic to crucifers and identification of Alternaria brassicicola field isolates highly resistant to both dicarboximides and phenylpyrroles. Crop Protection, 23, 481-488. Doi: 10.1016/j.cropro.2003.10.003

JOHNSON, D.R., WYSE, D.L., JONES, K.J. (1996). Controlling Weeds with Phytopathogenic Bacteria. Weed Technology, 10, 3, 621-624. Doi: 10.1017/S0890037X00040549

KHAN, Z.R., JAMES, D.G., MIDEGA, C.A.O., PICKETT, J.A. (2008). Chemical ecology and conservation biological control. Biological Control, 45, 2, 210-224. Doi: 10.1016/j.biocontrol.2007.11.009

LI, Y., SUN, Z., ZHUANG, X., XU, L., CHEN, S., LI, M. (2003). Research progress on microbial herbicides. Crop Protection, 22, 2, 247-252. Doi: 10.1016/S0261-2194(02)00189-8

MCFADYEN, R.E.C. (1998). BIOLOGICAL CONTROL OF WEEDS. Annual Review of Entomology, 43, 1, 369-393. Doi: 10.1146/annurev.ento.43.1.369

MESSING, R.H., WRIGHT, M.G. (2006). Biological control of invasive species: Solution or pollution? Frontiers in Ecology and the Environment, 4, 3, 132-140. Doi: 10.1890/1540-9295(2006)004[0132: BCOISS]2.0.CO;2

PABLO FERRER-GALLEGO, P., BOISET, F. (2015). Lectotypification of the fountain grass Cenchrus setaceus (Poaceae: Paniceae). Phytotaxa, 218, 2, 171-176. Doi: 10.11646/phytotaxa.218.2.7

PACANOSKI, Z. (2015). Bioherbicides. In A. Price, J. Kelton, \& L. Sarunaite (Eds.), Herbicides, Physiology of Action, and Safety, 253-274. Doi: 10.5772/61528

PESHIN, R., ZHANG, W. (2014). Integrated Pest Management and Pesticide Use. En Integrated Pest Management, 3. Doi: 10.1007/978-94-007-7796-5_1

POULIN, J., WELLER, S.G., SAKAI, A.K. (2005). Genetic diversity does not affect the invasiveness of fountain grass (Pennisetum setaceum) in Arizona, California and Hawaii. Diversity and Distributions, 11, 3, 241-247. Doi: 10.1111/j.1366-9516.2005.00136.x

RAHLAO, S.J., MILTON, S.J., ESLER, K.J., BARNARD, P. (2014). Performance of invasive alien fountain grass (Pennisetum setaceum) along a climatic gradient through three South African biomes. South African Journal of Botany, 91, 43-48. Doi: 10.1016/j.sajb.2013.11.013

REICHARD, S.E. (1997). Prevention of Invasive Plant Introductions on National and Local Levels. In J. O. Luken J. W. Thieret (Eds.), Assessment and Management of Plant Invasions, 215-227. Springer. Doi: 10.1007/978-1-4612-1926-2_16

RODRÍGUEZ-CABALLERO, G., FERNÁNDEZ-LÓPEZ, M., FERNÁNDEZ-GONZÁLEZ, A. J., ROLDÁN, A. (2017). Striking alterations in the soil bacterial community structure and functioning of the biological N cycle induced by Pennisetum setaceum invasion in a semiarid environment. Soil Biology and Biochemistry, 109, 176-187. Doi: 10.1016/j.soilbio.2017.02.012

SINDEN, J., HESTER, S., ODOM, KALISCH, SILlITOE, J., CACHO, O. (2004). The economic impact of weeds in Australia. En CRC for Australian Weed Management, 20.

TEBEEST, D.O. (1996). Biological Control of Weeds with Plant Pathogens and Microbial Pesticides11Published with the approval of the Director, Arkansas Agricultural Experiment Station, Manuscript No. 95053. En D. L. Sparks (Ed.), Advances in Agronomy, 56, 115-137. Academic Press. Doi: 10.1016/S0065-2113(08)60180-7 
THOMMA, B.P.H.J. (2003). Alternaria spp.: from general saprophyte to specific parasite. Molecular Plant Pathology, 4, 4, 225-236. Doi: 10.1046/J.1364-3703.2003.00173.X

THRANE, U. (1999). Fusarium. In: Carl A. Batt, Mary Lou Tortorello (Eds), Encyclopedia of Food Microbiology (2nd Edition), 76-81. Academic Press. Doi: 10.1016/B978-0-12-384730-0.00141-5.

TRONCOSO-ROJAS, R., TIZNADO-HERNANDEZ, M. (2014). Alternaria alternata (Black Rot, Black Spot). In: Silvia Bautista-Baños (Ed.), Postharvest Decay, 147-187. Academic Press. Doi: 10.1016/B978-0-12-411552-1.00005-3

VAN WILGEN, B.W., MORAN, V.C., HOFFMANN, J.H. (2013). Some Perspectives on the Risks and Benefits of Biological Control of Invasive Alien Plants in the Management of Natural Ecosystems. Environmental Management, 52, 3, 531-540. Doi: 10.1007/s00267-013-0099-4

WALENTOWITZ, A.J., IRL, S.D.H., ACEVEDO RODRÍGUEZ, A.J., PALOMARES-MARTÍNEZ, Á., VETTER, V., ZENNARO, B., MEDINA, F.M., BEIERKUHNLEIN, C. (2019). Graminoid Invasion in an Insular Endemism Hotspot and Its Protected Areas. Diversity, 11, 10, 192. Doi: $10.3390 / \mathrm{d} 11100192$

WHITE, T., BRUNS, T., LEE, S., TAYLOR, J., INNIS, M., GELFAND, D., SNINSKY, J. (1990). Amplification and Direct Sequencing of Fungal Ribosomal RNA Genes for Phylogenetics. En Pcr Protocols: A Guide to Methods and Applications, 31, 315-322.

WOUDENBERG, J.H.C., SEIDL, M.F., GROENEWALD, J.Z., DE VRIES, M., STIELOW, J.B., THOMMA, B.P.H.J., CROUS, P.W. (2015). Alternaria section Alternaria: Species, formae speciales or pathotypes? Studies in Mycology, 82, 1-21. Doi: 10.1016/j.simyco.2015.07.001 